\title{
KEEFEKTIFAN MANAJEMEN KELOMPOK KERJA GURU TAMAN KANAK-KANAK GUGUS I TK KECAMATAN MANGUHARJO KOTA MADIUN
}

\author{
Alisa Alfina, Farida Hanum \\ TK Islam Al Irsyad madiun, Universitas Negeri Yogyakarta \\ alisaalfina@yahoo.co.id
}

\begin{abstract}
Abstrak
Penelitian ini bertujuan untuk mengetahui keefektifan manajemen KKG TK Gugus I TK Kecamatan Manguharjo Kota Madiun yang meliputi: 1) perencanaan, 2) pengorganisasian, 3) pelaksanaan, dan 4) pengontrolan. Penelitian ini adalah penelitian evaluasi kualitatif. Model evaluasi yang digunakan adalah Center for the Study of Evaluation (CSE) dan University of California in Los Angeles (UCLA). Hasil Penelitian menunjukkan sebagai berikut: 1) perencanaan KKG TK selama ini tidak efektif, 2) pengorganisasian di KKG TK tidak efektif, 3) pelaksanaan kegiatan KKG TK tidak efektif, dan 4) Pengontrolan kegiatan di KKG TK tidak efektif. Yang menjadi kendala terbesar dari ketidak efektifan manajemen KKG TK Gugus I Kecamatan Manguharjo Kota Madiun adalah kemampuan sumber daya manusia, pemahaman tentang pentingnya KKG, dan biaya dalam pelaksanaan KKG TK.

Kata kunci: Manajemen KKG TK, Keefektifan manajemen pendidikan, Kelompok Kerja Guru Taman kanak-kanak.

\section{EFFECTIVENESS OF TEACHER WORKING GROUP MANAGEMENT KINDERGARTEN FORCE I SUB MANGUHARJO MADIUN CITY}

\begin{abstract}
This study aims to determine the effectiveness of the management of the Cluster I KKG TK Manguharjo sub-distric Madiun City which includes: 1) planning, 2) organization, 3) implementation, and 4) control. This study is an evaluation using qualitative approach. Model evaluation is Center for the Study of Evaluation (CSE) dan University of California in Los Angeles (UCLA). The research results show the following: 1) the planning for KKG kindergarten is ineffective, 2) the organizingin KKG kindergartenis ineffective, 3) Theimplementation of KKG kindergarten ineffective, and 4) the controlling activities in KKG kindergarten are ineffective. The biggest obstacle of management ineffectiveness of KKG Kindergarten Cluster I Manguharjo sub-distric, Madiun City is the ability of human resources, the understanding of the importance of $K K G$ and $K K G$ implementation costs in kindergarten.
\end{abstract}

Keywords: Management of KKGTK, the effectiveness of management education, the working group of kindergarten teachers. 


\section{Pendahuluan}

Pendidikan anak sejak usia dini sangat penting, maka diperlukan guru untuk anak usia dini atau biasa disebut guru Taman kanak-kanak (TK) yang profesional agar tidak salah dalam mendidik. Pemerintah telah melakukan berbagai cara untuk meningkatkan kualitas guru melalui pendidikan dan latihan, program penyetaraan pendidikan serta pembinaan dan pengembangan profesionalitas guru TK. Upaya pemerintah meningkatkan profesionalitas guru bertujuan untuk meningkatkan keterampilan mengajar, penguasaan materi yang akan diajarkan, komitmen terhadap tugas, serta memotivasi guru untuk melaksanakan pembelajaran dengan baik.

Dalam Peraturan Menteri Pendidikan Nasional Republik Indonesia Nomor 58 Tahun 2009, dituliskan bahwa seorang guru TK harus dimiliki standar kompetensi dan kualifikasi tertentu antara lain: (1) memiliki kualifikasi akademik minimum S1/D4, (2) memiliki kompetensi sebagai agen pembelajaran yaitu kompetensi pedagogik, kepribadian, sosial, dan profesional, dan (3) memiliki sertifikat pendidik.

Perwujudan usaha meningkatkan profesionalitas guru TK bisa melalui pelatihan, penulisan karya ilmiah dan pertemuan di Kelompok Kerja Guru TK (KKG TK). Forum KKGTK merupakan salah satu forum pembinaan guru untuk meningkatkan profesionalitas guru. Dengan demikian KKG TK memiliki peranan yang penting dalam mendukung pengembangan kompetensi guru. Dalam mewujudkan peran KKG TK untuk pengembangan profesionalitas guru, maka peningkatan kinerja KKG TK merupakan masalah yang mendesak untuk bisa direalisasikan, sehingga KKG TK bisa efektif meningkatkan profesionalitas guru.

KKG TK Gugus I Kecamatan Manguharjo Kota Madiun selama ini belum pernah dilakukan evaluasi tentang keefektifan manajemennya. Evaluasi keefektifan manajemen KKG TK adalah melihat bagaimana manajemen KKG TK sebagai suatu sistem. Melalui evaluasi diharapkan akan diketahui apa yang sedang berjalan, apa yang tidak berjalan, apa yang bisa diubah, dan apa yang harus dipertahankan. Selain itu evaluasi juga untuk mengetahui sejauhmana pelaksanaan manajemen KKG TK bisa berjalan efektif. Apabila ada kendala apa yang penyebabnya dan apa upaya yang perlu dilakukan dalam mengatasi kendala-kendala tersebut.

\section{Manajemen KKG TK}

Ruang lingkup manajemen KKG bisa terdiri dari perencanaan, pengorganisasian, pelaksanaan dan pengontrolan. Perencanaan yaitu merencana apa yang akan menjadi kegiatan dalam pertemuan KKG yang biasa dinamakan program kerja KKG. Pengorganisasian meliputi kepemimpinan, koordinasi dan kerjasama anggota, pelaksanaan merupakan pelaksanaan program yang sudah direncanakan, dan pengontrolan merupakan kegiatan monitoring terhadap pelaksanaan dan pencapaian tujuan.

Fungsi manajemen KKG TK menurut Buku Pedoman Kinerja Gugus (2010: 13) adalah: 1) menyusun program kerja Gugus TK bersama kepala TK, pengawas TK/SD dan nara sumber, 2) menampung dan memecahkan masalah yang dihadapi guru dalam pelaksanaan pembelajaran melalui pertemuan, diskusi, simulasi mengajar, demonstrasi, pembuatan dan penggunaan alat peraga serta permainan edukatif. 3) bersama-sama mengembangkan desain pembelajaran TK beserta silabusnya, meningkatkan pelaksanaan pembelajaran di TK, penilaian dan pengembangan profesionalisme guru TK.

Tujuan KKG TK bisa terwujud sebagai wadah PKB yang apabila dimanajemen dengan baik. Peranan manajemen Gugus sangat berpengaruh besar untuk mencapai tujuan. Kemampuan memanajemen pengurus Gugus juga menjadi salah satu hal yang harus dipertimbangkan dalam KKG TK, sehingga KKG TK efektif dan bisa mencapai tujuan yang diharapkan, yaitu bisa meningkatkan profesionalitas guru. 
Pelaksanaan program manajemen Gugus TK yang efektif tercantum dalam buku Pedoman Kinerja Gugus TK (2009: 20) dapat dibangun melalui: (1) pertemuan yang bermanfaat; (2) pengambilan keputusan yang bijaksana; (3) komunikasi yang efektif; (4) peraturan yang jelas, dan (5) pendelegasian tugas yang tepat.

Keefektifan

Keefektifan merupakan ukuran keberhasilan dari suatu tindakan. Wijayanto (2012: 7) menyatakan "efektifitas adalah kemampuan untuk mencapai sasaran. Efektifitas terkait dengan terminologi doing the right things atau melakukan sesuatu yang benar, sehingga diistilahkan menjadi berhasil guna".

Mulyasa (2011: 83) berpendapat bahwa "efektifitas dapat dijadikan sebagai barometer untuk mengukur keberhasilan dalam pendidikan". Dalam upaya pengukuran ini terdapat dua istilah yang perlu diperhatikan, yaitu validasi dan evaluasi. Validasi merupakan ketepatan dan kebenaran dari hasil sebuah program, sedangkan evaluasi merupakan analisa kebaikan, kekurangan, keunggulan dan kelemahan.

Berdasarkan teori sistem, kriteria efektifitas harus mencerminkan keseluruhan siklus input-proses-output (Mulyasa, 2009: 82). Hal ini berkaitan dengan apa yang menjadi ruang lingkup manajemen. Apabila ruang lingkup manajemen efektif maka manajemen akan efektif. Keefektifan manajemen berhubungan dengan keefektifan perencanaan, pengorganisasian, pelaksanaan dan pengontrolan.

Tujuan yang ingin dicapai dalam penelitian ini adalah untuk mengetahui bagaimana keefktifan manajemen dari KKG TK Gugus I yang terdiri dari: 1) perencanaan, 2) pengorganisasian, 3) pelaksanaan, dan 4) pengontrolan.

\section{Metode Penelitian}

Penelitian ini adalah penelitian evaluasi kualitatif. Model evaluasi yang digunakan adalah Center for the Study of
Evaluation (CSE) dan model University of California in Los Angeles (UCLA). Menurut Fernandes (1984: 11) model CSE-UCLA melalui empat tahap, yaitu: (1) needs assessment, (2) program planing, (3) formative evaluation, dan (4) summative evaluation. Secara grafis tahapan tersebut dapat dilihat pada tampilan Gambar 5 dibawah ini:

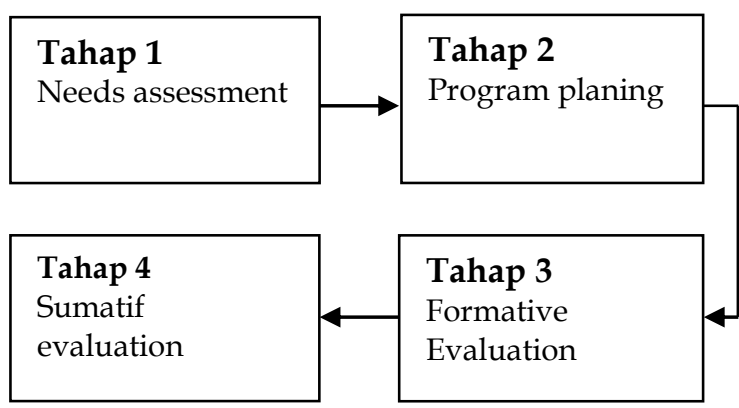

Gambar 1. Tahap Evaluasi Model CSE (Sumber: Fernandes, 1984: 11)

Adapun empat langkah seperti tersebut di atas secara lebih rinci dapat diuraikan masing-masing sebagai berikut:

Needs Assessment

Pada tahap ini evaluator memutuskan perhatian pada penentuan masalah. Tahap ini merupakan tahap persiapan sebelum membuat perencanaan, dan pertanyaan yang diajukan adalah:

a. Hal-hal apakah yang perlu dipertimbangkan sehubungan dengan keberadaan program KKG TK.

b. Kebutuhan apakah yang terpenuhi sehubungan dengan adanya pelaksanaan program KKG TK.

c. Tujuan jangka panjang apakah yang dapat dicapai melalui program KKG TK.

\section{Program Planning}

Tahap perencanaan program, evaluator mengumpulkan data yang terkait langsung dengan kegiatan KKG TK yang akan direncanakan dan mengarah pada pemenuhan kebutuhan yang diidentifikasikan pada tahap ke satu. Dalam tahap perencanaan ini program dievaluasi dengan cermat untuk mengetahui apakah perencanaan kegiatan KKG TK telah disusun berdasarkan hasil kebutuhan. 
Evaluasi tahap ini tidak lepas dari tujuan yang telah dirumuskan.

Formative Evaluation

Tahap formatif adalah tahap dimana perencanaan KKG dilaksanakan dan, bagaimana pengorganisasiannya. Pada tahap ini evaluator memutuskan perhatian pada keterlaksanaan program dan bagaimana mengorganisasi sumber daya manusia (anggota) dalam melaksanakan program yang telah direncanakan. Dengan demikian, evaluator diharapkan betulbetul terlibat program karena harus mengumpulkan data dan berbagai informasi dari pengembangan program.

Summative evaluation

Tahap sumatif adalah merupakan tahap pengontrolan untuk mengetahui sejauh mana pelaksanaan KKG, apakah kegiatannya sudah sesuai dengan tujuan yang diharapkan. Pada tahap ini evaluator diharapkan dapat mengumpulkan semua data tentang hasil dan dampak program. Melalui evaluasi summatif akan diketahui apakah tujuan yang dirumuskan untuk program sudah tercapai, dan jika belum dicari bagian mana yang belum dan apa penyebabnya.

Tempat dan Waktu Penelitian

Tempat penelitian adalah di Gugus I Kecamatan Manguharjo Kota Madiun yang terdiri dari 6 TK yaitu: 1) TK Kartika IX-31 sebagai Gugus Inti, 2) TK DW Ngegong, 3) TK Taman Indria Winongo, 4) TK Islam Al Huda, 5) TK Islam Bahkti Winongo, 6) TK Kuntum Mekar. Sedangkan waktu penelitiannya dilakukan selama 5 bulan, dimulai pada awal bulan November 2012 sampai dengan akhir Maret 2013.

\section{Subjek dan Objek Penelitian}

Subjek penelitian ini adalah semua guru dan kepala sekolah di KKG TK Gugus I Kecamatan Manguharjo kota Madiun. Subjek penelitian berjumlah 30 orang termasuk 6 kepala sekolah. Adapun yang menjadi objek penelitian ini adalah semua aktivitas yang ada di KKG TK Gugus I Kecamatan Manguharjo Kota Madiun, terutama aktifitas manajemennya. Objek penelitian merupakan situasi sosial di lokasi penelitian yang ingin diketahui mengenai apa yang terjadi di dalamnya. Kejadian dan peristiwa di lokasi penelitian mencakup kegiatan, peristiwa, dan orangorang di suatu tempat/waktu tertentu.

\section{Teknik dan Instrumen Pengumpulan Data}

Teknik pengumpulan data yang dipakai pada penelitian ini adalah dengan menggunakan (1) observasi, (2) wawancara, (3) dokumentasi, (4) triangulasi/ gabungan dari tiga teknik sebelumnya.

\section{Keabsahan Data}

Dalam penelitian kualitatif data yang diperoleh melalui hasil wawancara, observasi, maupun angket tentu masih mengandung nilai-nilai subjektif. Untuk menghindari subjektivitas data tersebut, penting untuk dilakukan pengujian keabsahan dengan empat uji yaitu: (1) uji kredibilitas, (2) uji transferabilitas, (3) uji dependabilitas, dan (4) uji konfirmabilitas. Secara singkat empat tahap uji keabsahan data tersebut akan diuraikan di bawah ini.

\section{Uji Kredibilitas}

Uji kredibilitas dimaksudkan untuk meyakinkan kepada pembaca dan pemakai hasil penelitian agar lebih mempercayai bahwa data yang diperoleh merupakan data yang dapat diandalkan. Salah satu instrumen yang digunakan dalam tahap uji kredibilitas ini adalah dengan melakukan triangulasi teknik, triangulasi sumber, dan triangulasi waktu. Pengujian kredibilitas data tentang keefektifan manajemen KKG TK Gugus I dilakukan dengan observasi dan wawancara pada waktu yang berbedabeda. Konsistensi jawaban atas pertanyaan yang diajukan pada waktu tertentu dilakukan lagi pada waktu yang berbeda demikian seterusnya.

\section{Uji Transferabilitas}

Uji transferabilitas merupakan uji yang melibatkan pihak lain (eksternal) 
yang mau dan bisa menerapkan/menggunakan hasil penelitian naturalistik tersebut ke dalam konteks situasi sosial lain. Apabila pembaca laporan penelitian memperoleh gambaran yang semakin jelasnya, "semacam apa" suatu hasil penelitian dapat diberlakukan (transferability), maka laporan tersebut memenuhi standar transferabilitas, Sanafiah Faisal (Sugiyono, 2011: 374).

\section{Uji Dependabilitas}

Proses uji dependabilitas data penelitian ini dilakukan dengan cara mengaudit/menginventarisir seluruh proses penelitian yang sudah dilakukan. Dengan cara ini, maka data penelitian yang ada benar-benar merupakan data yang diperoleh melalui proses dari seting penelitian yang telah ditetapkan sebelumnya.

\section{Uji Konfirmabilitas}

Dalam proses uji konfirmabilitas dilakukan secara bersamaan dengan proses uji dependabilitas. Uji konfirmabilitas pada dasarnya hampir sama dengan uji dependabilitas, hanya saja pada uji konfirmabilitas orang-orang independen yang terlibat dalam pengujiannya lebih banyak sedangkan uji dependabilitas orang-orang independen yang terlibat lebih sedikit. Menguji konfirmabilitas berarti menguji hasil penelitian, dikaitkan dengan proses yang dilakukan. Apabila hasil penelitian merupakan fungsi dari proses penelitian yang dilakukan, maka penelitian tersebut telah memenuhi standar konfirmabilitas (Sugiyono, 2011: 374).

\section{Teknik Analisis Data}

Sebelum dilakukan analisis, data yang diperoleh dengan menggunakan tiga teknik seperti disebut di atas, dilakukan tahap reduksi data, klasifikasi data, dan verifikasi data.

Guna mengetahui tingkat keefektifan proses manajemen KKG TK Gugus I dilakukan analisis data hasil dari reduksi, klasifikasi, dan observasi. Hasil pengukuran keefektifan proses manajemen KKG TK Gugus I dapat diketahui apabila pencapai- an indikator yang ada (realita) dibandingkan dengan yang diharapkan/tertinggi dikalikan 100. Adapun formula yang digunakan seperti berikut ini.

$$
\% \text { Keefektifan }=\frac{\sum \text { Skor }}{\sum \text { Skor Tertinggi }} \times 100
$$

Sedangkan kriteria yang digunakan untuk menilai tingkat keefektifan proses manajemen KKG TK gugus I adalah sebagai berikut:

$\begin{array}{ll}\text { Sangat efektif } & : 85-100 \% . \\ \text { Efektif } & : 75-84 \% . \\ \text { Cukup efektif } & : 60-74 \% . \\ \text { Kurang efektif } & : 0-59 \% .\end{array}$

\section{Hasil Penelitian dan Pembahasan}

Berdasarkan deskripsi data yang sudah disajikan di atas, selanjutnya perlu dianalisis agar bisa dievaluasi bagaimana keefektifan manajemen KKG TK dan apa saja yang menjadi kendala-kendala dalam manajemen KKG TK Gugus I Kecamatan Manguharjo kota Madiun. Hal ini juga untuk menjawab apa yang menjadi pertanyaan peneliti, dan supaya bisa memberi masukan-masukan untuk mengatasi kendala-kendala dalam memanajemen KKG TK.

\section{Perencanaan}

Perencanaan sangat penting dalam proses manajemen. Semua aktifitas manajemen tidak bisa berjalan tanpa ada perencanaan. KKG TK memerlukan perencanaan agar disetiap kegiatannya efektif bisa bermanfaat untuk guru dalam upaya meningkatkan profesionalitasnya. Dalam perencanaan KKG TK hakikatnya adalah proses pengambilan keputusan kegiatan apa yang akan dilakukan di setiap pertemuan KKG TK yang bisa meningkatkan profesionalitas guru TK.

Perencanaan dalam kegiatan KKG TK dibuat untuk memastikan kemana arah dan tujuan organisasi, sehingga tahu apa saja yang seharusnya dilakukan, kapan 
melakukannya, bagaimana melakukannya, bagaimana mencegah permasalahan, serta bagaimana mengatasi kendala-kendala dalam proses pelaksanaan dalam rangka mewujudkan visi dan misi organisasi. Persentase jawaban yang diberikan dalam perencanaan, sebesar $40 \%$ atau 12 orang dari 30 orang yang memberikan jawaban bahwa perencanaan dibuat jika hanya ada lomba. Harapannya perencanaan dibuat tidak sekedar akan ada lomba, namun menjadi kebutuhan dari organisasi KKG TK.

Proses perencanaan idealnya melalui 3 tahap, yaitu tahap persiapan, tahap penyusunan dan tahap pengesahan. Tahap persiapan merupakan tahap need assesment, yaitu tahap untuk mengetahui sejauh mana kesiapan Tim dalam mempersiapkan penyusunan perencanaan program.

Hasil penelitian menunjukkan bahwa pada tahap persiapan, yang menjadi tim perencana adalah pengurus Gugus, pengurus KKG TK dan pengurus KKKTK. Pembentukan tim tujuannya untuk menentukan siapa yang mengkoordinasi penyusunan perencanaan program. Tim perlu mendapat pelatihan dengan harapan nantinya tim perencanaan bisa melaksanakan tugas dengan baik dan tepat sasaran. Tim belum pernah mendapatkan pembekalan tentang bagaimana memanajemen KKG TK. Selama ini yang menjadi pedoman manajemen KKG TK adalah Buku Panduan Kinerja Gugus yang diberikan oleh Dinas.

Tahap penyusunan program merupakan tahap program planing, ditemukan dari hasil penelitian menunjukkan bahwa selama ini penyusunan perencanaan program hanya untuk jangka pendek saja. Program jangka panjang baru ada setelah Gugus I akan maju untuk lomba dan harus memenuhi syarat administrasi bahwa dalam gugus harus ada perencanaan jangka pendek dan jangka panjang.

Proses penyusunan program, dalam implementasinya selama ini pengurus berkumpul dan bermusyawarah untuk menentukan program sementara. Langkah selanjutnya program sementara disosialisasikan ke anggota, untuk dimusya- warahkan lebih lanjut. Setelah mendapat kesepakatan bersama program disusun kembali sesuai kesepakatan, kemudian disahkan. Pengesahan program selama ini hanya disahkan oleh ketua Gugus. Hanya saat ada lomba saja pengesahan ada tanda tangan Dinas.

Meski perencanaan selama ini selalu dibuat namun belum maksimal untuk benar-benar diharapkan bisa direalisasikan. Perencanaan belum ada ruh harapan agar benar-benar bisa mencapai tujuan diadakannya KKG TK. Hal ini sesuai dengan pendapat Kasali (2011: 233) yang menyatakan sebuah perencanaan tidak bisa berdiri sendiri. Sebuah rencana yang baik membutuhkan rencana-rencana tindakan yang dilengkapi dengan pengendalian dan back-up system.

\section{Pengorganisasian}

Setelah ditetapkan perencanaan, fungsi manajemen selanjutnya adalah pengorganisasian. Menurut Griffin (2004: 322) pengorganisasian adalah memutuskan bagaimana cara terbaik untuk mengelompokkan aktifitas dan sumber daya organisasi. Pengorganisasian merupakan proses bagaimana mengkoordinasi orang-orang dalam organisasi supaya dalam melaksanakan kegiatan yang sudah direncanakan dan diprogramkan bisa sesuai dengan perencanaan. Pengkoordinasian ini penting, karena tanpa ada pengkoordinasian, orang-orang yang berada dalam organisasi tidak akan tahu arah untuk apa dan bagaimana melaksanakan tugasnya.

Organisasi sebenarnya merupakan kumpulan dari manusia yang memiliki visi dan misi yang sama. Sehingga dalam organisasi manusia merupakan komponen utama yang melaksanakan proses kegiatan organisasi agar bisa mencapai visi dan misinya. Hal ini seperti yang diungkapkan oleh Kasali dalam bukunya Change (2011: 104) yang menuliskan bahwa manusia adalah komponen yang melakukan proses organisasi seperti komunikasi, pengambilan keputusan, dan pemecahan masalah. Sehingga bisa dikatakan organisasi me- 
rupakan sekumpulan manusia yang saling berkomunikasi untuk memecahkan masalah dan memutuskan ke arah mana tujuan yang hendak dicapai sekaligus bagaimana cara mencapainya.

Tahap formative evaluation merupakan proses pengorganisasian dan pelaksanaan, dimana pada tahap ini akan diketahui sejauh mana pemahaman anggota organisasi dalam menjalankan perencanaan program. Peranan pemimpin dalam organisasi sangat berpengaruh terhadap keberhasilan mencapai visi dan misi organisasi.

Dalam penelitian ini yang dijadikan pengukuran keefektifan dari organisasi KKG TK adalah bagaimana kepemimpinan dalam organisasi, bagaimana kepengurusannya dalam melaksanakan tugasnya, dan bagaimana budaya dalam organisasi. Hasil penelitian pengorganisasian KKG TK Gugus I Kecamatan Manguharjo Kota Madiun persentase jawaban yang diperoleh $40 \%$ atau 12 orang menyatakan pemimpin tidak memahami dan $40 \%$ atau 12 orang sangat tidak memahami tentang pengorganisasian.

Di organisasi KKG TK terdiri dari 3 golongan yang kategorikan menurut lama mengajar, umur, pangkat golongan dan status, yang bisa dilihat pada tabel 23 . Golongan pertama yaitu golongan muda, yang dilihat dari segi umur maupun masa kerja masih relatif muda. Guru pada golongan ini masih dalam taraf belajar dan menyesuaikan, umumnya guru di golongan ini selalu ingin belajar dan telah memiliki skill iptek yang lebih baik dari golongan menengah dan tua. Namun dilihat dari partisipatifnya golongan muda lebih banyak menjadi pengikuti, dan belum berani memberikan mengeluarkan ide-ide kreatifnya.

Golongan pertama yaitu golongan muda, yang dilihat dari segi umur maupun masa kerja masih relatif muda. Guru pada golongan ini masih dalam taraf belajar dan menyesuaikan, umumnya guru di golongan ini selalu ingin belajar dan telah memiliki skill iptek yang lebih baik dari golongan menengah dan tua. Namun di- lihat dari partisipatifnya golongan muda lebih banyak menjadi pengikuti, dan belum berani memberikan mengeluarkan ide-ide kreatifnya.

Golongan pertama yaitu golongan muda, yang dilihat dari segi umur maupun masa kerja masih relatif muda. Guru pada golongan ini masih dalam taraf belajar dan menyesuaikan, umumnya guru di golongan ini selalu ingin belajar dan telah memiliki skill iptek yang lebih baik dari golongan menengah dan tua. Namun dilihat dari partisipatifnya golongan muda lebih banyak menjadi pengikuti, dan belum berani memberikan mengeluarkan ide-ide kreatifnya.

Golongan menengah dengan umur dan masa kerja menengah adalah golongan produktif yang telah memiliki pengalaman cukup dalam organisasi KKG TK. Golongan ini aktif dalam berpartisipatif dan sudah berani mengeluarkan banyak ide dan masukan untuk kemajuan dan kegiatan KKG TK. Golongan ini bisa dikatakan senantiasa ingin membuat inovasi-inovasi baru.

Sedangkan golongan ke tiga adalah golongan matang dimana guru yang telah memiliki masa kerja lebih lama dari golongan satu dan dua juga umur dan satatus golongan PNS yang sudah golongan IIIb ke atas. Golongan ini secara umum belum memiliki skill yang baik dalam hal iptek dan merasa sudah tua jika harus mengikuti perkembangan untuk terus belajar.

Tabel 1. Penggolongan Organisasi KKG TK

\begin{tabular}{ll}
\hline $\begin{array}{c}\text { Nama } \\
\text { Golongan }\end{array}$ & \multicolumn{1}{c}{ Keterangan Golongan } \\
\hline Muda & $\begin{array}{l}\text { Masa kerja dibawah 5 tahun, } \\
\text { guru baru, non pns, umur } \\
\text { dibawah } 30 \text { tahun }\end{array}$ \\
Menengah & $\begin{array}{l}\text { Masa kerja antara 5 s.d 10 } \\
\text { tahun, pns baru gol IIb, }\end{array}$ \\
Matang & $\begin{array}{l}\text { Masa kerja 10 s.d 20 th, pns } \\
\text { golongan III b }\end{array}$ \\
Tua & $\begin{array}{l}\text { Masa Kerja diatas 20 th, pns } \\
\text { golongan II b maupun III b }\end{array}$ \\
\hline
\end{tabular}

Sumber: Data Hasil Olahan 
Ketiga golongan di atas yang menjadi perhatian adalah ketika program KKG TK ingin berpacu dan berkreatifitas, terutama dalam ilmu dan teknologi harus bersabar untuk menunggu langkah golongan ke tiga. Golongan ke tiga tidak mau ditinggal namun juga tidak mau di dahului. Apabila ditinggal merasa dilangkahi, namun golongan pertama dan ke dua tidak sabar jika harus menunggu golongan ke tiga.

Fenomena di atas menjadi tantangan organisasi Gugus I TK Kecamatan Manguharjo Kota Madiun, terutama pemimpin Gugus yang masih golongan II dalam jabatan PNS. Hal ini juga menjadi perhatian, mengingat anggota KKG TK adalah guru TK. Guru TK dituntut untuk bisa meningkatkan skill dalam mengajarnya, karena anak-anak usia dini setiap tahun memiliki kemampuan perkembangan yang terus berubah dan meningkat pesat. Hal tersebut didukung dengan sudah semakin tinggi berpendidikan masyarakat sehingga memiliki kesadaran dan pengetahuan yang luas akan pentingnya pendidikan sejak usia dini.

Ketiga golongan dengan ciri khas masing-masing menjadi tantangan pemimpin di Gugus I untuk membentuk budaya baru yang lebih baik di organisasi. Hambatan terberat adalah cara berpikir anggota organisasi yang sebagian besar masih memakai cara lama sehingga memperlambat proses kemajuan kegiatan KKG TK untuk berinovasi dan berkembang. Kemampuan pemimpin Gugus yang menjadi kunci pokok dalam kemajuan KKG TK meski sudah memiliki pengalaman memimpin namun masih perlu banyak belajar baik secara teori maupun praktek bagaimana menggerakkan organisasinya.

Tantangan pemimpin adalah bagaimana agar bisa mengubah cara berpikir anggotanya terutama yang golongan kepegawaian dan umurnya di atas ketua Gugus, sehingga organisasi KKG TK semakin baik, dan tidak stagnan. Kesulitan Pemimpin dalam mengubah budaya organisasi, dikarenakan golongan matang dan menengah masih memiliki pola dan cara berpikir lama, sedangkan golongan menengah merasa enggan karena takut dikatan tidak memiliki sopan santun.

Dibutuhkan seorang pemimpin yang mampu memiliki strategi dan skill khusus dalam mewujudkan perubahan organisasi. Pemimpin perubahan hendaknya memiliki wawasan yang luas dan mampu mengkomunikasikan visi dan misi organisasi pada anggotanya. Pemimpin perubahan hendaknya memiliki skill manajemen dan mampu membuat perencanaan perubahan serta strategi melakukannya. Maka pemimpin perubahan adalah pemimpin yang visioner, memeiliki cara berpikir yang maju dan positif, memiliki skill, memiliki kesungguhan dan kemampuan untuk bertindak dan tahan terhadap cobaan.

\section{Pelaksanaan}

Pelaksanaan masih dalam tahap formative evaluation. Pelaksanaan KKG TK adalah sangat penting karena dalam pelaksanaan bisa dilihat bagaimana kualitas KKG TK dan apakah KKG TK benarbenar sudah bisa memenuhi fungsinya sehingga bisa mencapai tujuannya. Keefektifan pelaksanaan dalam penelitian ini diukur dengan melihat ketepatan waktu pelaksanaan, antusias anggota, dan keberadaan narasumber.

Penelitian pada pelaksanaan KKG TK Gugus I Kecamatan Manguharjo Kota Madiun diperoleh hasil bahwa hanya $20 \%$ atau 6 orang menyatakan bahwa pelaksanaan sesuia dengan perencanan, antusias anggota dalam mengikuti kegiatan sebanyak $40 \%$ atau 12 orang dan keberadaan narasumber disetiap kegiatan yang menyatakan setuju hanya $20 \%$ atau 6 orang.

Dari hasil pengamatan, bahwa pelaksanaan memang sudah dilaksanakan sesuai prosedur perencanaan dan selalu ada pemateri serta kehadiran anggotar yang menunjukkan adanya indikasi kemauan dan kebutuhan akan pentingnya KKG TK. Namun kehadiran guru dalam kegiatan KKG TK bukan berarti KKG TK menjadi kebutuhan guru untuk dihadiri, 
namun sudah menjadi jadwal rutin dan alasan utamanya takut ketinggalan informasi kedinasan.

KKG TK lebih memiliki makna bukan sebagai tempat untuk pelatihan dan pembelajarn guru agar bisa menambah keterampilan dalam mengajar dan mendapatkan pengetahuan serta penambahan wawasan. Pemahaman anggota Gugus menghadiri pertemuan KKG TK lebih mendorong pada silaturahmi dan tidak ingin ketinggalan informasi kedinasan daripada sebagai wadah untuk meningkatkan kompetensi guru.

\section{Pengontrolan}

Pengontrolan merupakan proses summative evaluation untuk melihat dampak dari program. Pengontrolan adalah salah satu proses manajemen untuk mengetahui apakah program telah dilaksanakan dengan baik, sesuai target yang diharapkan. Dengan adanya pengontrolan akan diketahui apakah dalam proses pelaksanaan program ada kendala. Pengontrolan akan efektif bila ada standar program sebagai acuan keberhasilan pelaksanaan, proses monitoring dilakukan secara konsisten, dan ada pelaporan hasil kegiatan.

Penelitian pengontrolan kegiatan KKG TK Gugus I Kecamatan Manguharjo Kota Madiun diperoleh hasil bahwa keberadaan standar program $40 \%$ atau 12 orang, pelaksanaan monitoring kegiatan $60 \%$ atau 18 orang, dan laporan pertanggungjawaban hasil kegiatan $60 \%$ atau 18 orang menyatakan jarang dibuat. Hal ini menunjukkan bahwa pengontrolan selama ini belum maksimal dilaksanakan.

Pengontrolan salah satu merupakan cara untuk meningkatkan mutu manajemen. Pengontrolan yang dilakukan secara terus menerus secara rutin akan mencegah permasalahan dan akan membentuk kebiasaan baru yaitu terbiasa untuk selalu menyempurnakan pelaksanaan. Dampaknya akan diperoleh hasil yang maksimal dan bisa mengetahui letak kebaikan dan keburukan sebuah perencanaan.
Bukti fisik bahwa keberhasilan sebuah program adalah adanya laporan pertanggungjawaban hasil pelaksanaan proram. Pada laporan tercantum secara tertulis hasil evaluasi dan kendala-kendala dalam pelaksanaan program, sehingga bisa dipelajari untuk perencanaan selanjutnya.

Kendala Dalam Manajemen KKG TK dan Upaya dalam Mengatasinya

Dari hasil perolehan data penelitian, bahwa yang menjadi kendala dalam manajemen KKG TK Gugus I Kecamatan Manguharjo dan Kota Madiun bisa disimpulkan adalah dana, masalah skill SDM terutama penguru. Dana merupakan hal pokok untuk bisa membuat KKG TK bisa terus beraktifitas dan terus meningkatkan kualitas kegiatan. Namun dana yang berasal dari iuran belum mampu mengatasi masalah untuk bisa mendatangkan nara sumber yang kompeten.

Iuran dari anggota selama ini sangat minim. Sedangkan untuk bisa mendatangkan narasumber yang profesional secara rutin memerlukan biaya yang tidak sedikit. Mungkin selama ini pemerintah telah menyediakan dana untuk pelaksanaan kegiatan KKG TK, namun tidak tersosialisasikan dengan baik dan tidak semua KKG TK mendapatkan dana tersebut.

Adanya perubahan sistem dari pemerintah dimana guru dituntut untuk terus belajar dan mengikuti perkembangan jaman serta ilmu dan teknologi, serta kewajiban memiliki sertifikat pendidik dengan tambahan finansial yang tidak sedikit, membuat semua guru berpacu untuk mendapatkannya. Namun kenyataan dilapangan kemampuan guru untuk merubah budaya menjadi guru di jaman era globalisasi ternyata masih belum sepenuhnya sesuai harapan. Apalagi di kota kecil, dimana budaya dan wawasan guru sebagian besar masih berpikir dengan cara lama dan perlu waktu untuk bisa mengikuti cara baru.

Pemahaman dan motivasi guru dalam mengikuti kegiatan KKG TK juga 
menjadi kendala untuk memaksimalkan kegiatan KKG TK. Selama ini KKG TK identik dengan arisan, silaturahmi dan mendengarkan informasi kedinasan serta karena ketentuan dari dinas. Sehingga apabila kegiatan inti yaitu absensi, mendengarkan informasi dan saling menyapa sudah selesai, maka untuk melaksanakan kegiatan lainnya masih belum bisa dipastikan bisa terlaksana secara maksimal, apalagi metode pelaksanaannya masih stagnan dan tidak menarik.

\section{Simpulan}

Dari pembahasan seperti yang telah diuraikan di atas, maka penelititan yang berjudul: "Keefektifan Kelompok Kerja Guru Taman Kanak-kanak Gugus I Kecamatan Manguharjo Kota Madiun" dapat disimpulkan sebagai berikut:

1. Perencanaan KKG TK Gugus I Kecamatan Manguharjo Kota Madiun tidak efektif yang dibuktikan dengan persentase jawaban yang diberikan sebesar $40 \%$ atau 12 orang dari 30 orang yang memberikan jawaban bahwa perencanaan dibuat jika hanya ada lomba.

2. Pengorganisasian KKG TK Gugus I Kecamatan Manguharjo Kota Madiun tidak efektif. Hal ini dibuktikan dengan persentase jawaban yang diberikan bahwa ternyata $40 \%$ atau 12 orang menyatakan pemimpin tidak memahami dan $40 \%$ atau 12 orang sangat tidak memahami tentang pengorganisasian.

3. Pelaksanaan KKG TK Gugus I Kecamatan Manguharjo Kota Madiun secara umum juga tidak efektif. Hal ini dibuktikan dengan persentase jawaban yang diberikan bahwa ternyata hanya $20 \%$ atau 6 orang menyatakan bahwa pelaksanaan tidak sesuai dengan perencanan, antusias anggota dalam mengikuti kegiatan sebanyak $40 \%$ atau 12 orang dan keberadaan narasumber disetiap kegiatan yang menyatakan setuju hanya $20 \%$ atau 6 orang .

4. Pengontrolan kegiatan KKG TK Gugus I Kecamatan Manguharjo Kota Madiun tidak efektif. Hal ini dibuktikan dengan persentase jawaban yang diberikan bahwa ternyata $60 \%$ atau 18 orang menyatakan bahwa pengontrolan perencanaan program dan pelaksanaannya jarang dilakukan, keberadaan standar program $40 \%$ atau 12 orang menyatakan ada, dan laporan pertanggungjawaban hasil kegiatan $60 \%$ atau 18 orang menyatakan jarang dibuat.

5. Beberapa kendala yang dihadapi oleh KKG TK Gugus I Kecamatan Manguharjo Kota Madiun pada umumnya adalah keterbatasan dana, skill yang dimiliki oleh para pengurus, dan paradigma berpikir yang masih birokratis.

6. Upaya-upaya yang dilaksanakan oleh KKG TK Gugus I Kecamatan Manguharjo Kota Madiun selama ini dengan cara:

a. Iuran anggota.

b. Peningkatan skill kepada para pengurus.

c. Memberikan wawasan berpikir di luar kotak (out of the box).

\section{Implikasi}

1. Penyusunan perencanaan KKG TK memerlukan tim yang memiliki skill manajemen dan memahami cara membuat perencanaan meski sederhana. Perencanaan bila dalam disusun berdasarkan pada kebutuhan anggota organisasi dan direncana dengan baik, sesuai standar minimal yang telah ditentukan akan menghasilkan perencanaan yang efektif.

2. Pengorganisasian KKG TK Gugus I Kecamatan Manguharjo Kota Madiun, bila mampu merubah budaya anggota dalam organisasi dan merubah cara berpikir anggotanya akan meningkatkan keefektifan organisasi.

3. Implementasikan perencanaan dalam kegiatan KKG TK memerlukan strategi yang pas dan menarik, sehingga bisa mengkomunikasikan manfaat pertemuan KKG TK dan membuat anggota menyadari pentingnya kegiatan KKG TK sebagai institusi untuk meningkatkan profesionalitas guru. Pelaksanaan 
kegiatan KKG TK yang menarik akan menumbuhkan kesadaran guru, bahwa kegiatan KKG TK menjadi kebutuhan guru untuk menghadirinya, bukan hanya sebagai rutinitas, namun menjadi institusi yang bisa menambah wawasan guru dan meningkatkan profesionalitas guru. Maka pertemuan KKG TK akan menjadi efektif dan berfungsi sesuai fungsinya.

4. Sistem pengontrolan yang dilakukan secara konsisten dan terarah memperlihatkan kesungguhan dan pentingnya pelaksanaan kegiaatan KKG TK. Pengontrolan akan bisa cepat mendeteksi apa saja yang membuat pertemuan KKG TK menjadi tidak efektif.

Keterbatasan Penelitian

Dalam penelitian ini ada beberapa hal yang menjadi keterbatasan penelitian dikarenakan beberapa faktor. Keterbatasan penelitian ini menjadi kendala penelitian sehingga hasil dari penelitian kurang maksimal. Adapun keterbatan penelitian tersebut adalah:

1. Pada saat proses wawancara ada beberapa responden yang kurang terbuka. Responden bersedia diwawancara secara secara tertulis, sehingga beberapa jawabannya kurang mendalam dan kurang valid.

2. Saat dilakukan pengumpulan data, tempat penelitian sedang mempersiapkan akreditasi dan lomba lingkungan sekolah sehat sehingga informasi yang diharapkan peneliti kurang maksimal didapatkan karena data diperlukan dalam proses akreditasi dan lomba.

\section{Saran}

1. Agar perencanaan di KKG TK Gugus I Kecamatan Manguharjo Kota Madiun bisa berjalan efektif, maka perlu pembekalan dan pembinaan tim mengenai sistem perencanaan yang baik.

2. Agar dalam pengorganisasian KKG TK Gugus I Kecamatan Manguharjo Kota Madiun efektif, maka harus dilakukan pelatihan manajemen sumber daya manusia secara berkala.

3. Agar pelaksanaan KKG TK Gugus I Kecamatan Manguharjo Kota Madiun efektif, maka perlu mendatangkan nara sumber yang kompeten di bidangnya.

4. Agar pengontrolan kegiatan KKG TK Gugus I Kecamatan Manguharjo Kota Madiun efektif, maka perlu dilakukan monitoring secara periodik (berkala).

\section{DAFTAR PUSTAKA}

Depdiknas. (2008). Standar operasional penyelenggaraan KKG,MGMP. (2008). Standar pengembangan KKG,MGMP.

(2007). Peraturan menteri RI nomor 16, tahun 2007, tentang standar kualifikasi akademik dan kompetensi guru.

(2009). Peraturan menteri pendidikan nasional RI nomor 58, tahun 2009, tentang standar PAUD.

(2010). Peraturan menteri pendidikan nasional RI nomor 35, tahun 2010, tentang diklat fungsional . (2010). Pedoman kinerja gugus TK (2011). Buku pedoman pembinaan gugus PAUD.

(2012). Pedoman pengelolaan pengembangan kinerja berkelanjutan (PKB).

Fitzpatrick, J.L., Sanders, J.R., \& Worthen, B.R. (2004). Program evaluation (3rded.). America: Pearson Education.

Griffin, R.W. (2004). Manajemen(7rded.). (Terjemahan Gina Gania). Boston: Houghton Mifflin Company. (Buku Asli terbit tahun 2002).

Kasali, R., (2011). Change. Gramedia: Jakarta.

Mulyasa, E. (2011). Manajemen berbasis sekolah. Bandung: Remaja Rosdakarya

Sugiyono. (2011). Metode penelitian pendidikan. Bandung: Alfabeta.

Wijayanto, D. (2012). Pengantar manajemen. Jakarta: Kompas Gramedia. 